\title{
POLSKIE DOŚWIADCZENIA W KSZTAETOWANIU PO 1989 ROKU DEMOKRATYCZNEJ POLITYKI NARODOWOŚCIOWEJ
}

\section{Polish Experiences in Shaping Democratic National Policy after 1989}

The aim of this article is not to analyse the shaping of Polish national policy after 1989, that is, after the collapse of the communist system. The author focuses on its fundamental determinants, that is, factors accelerating or blocking the changes made. The subject of the considerations is government institutions, international and national legal regulations, the role of important politicians and the dynamics of changes still taking place among national and ethnic minorities.

Keywords: national policy, rights of national and ethnic minorities, ethnic and national minorities, regional languages, international law.

Jak przełomowe znaczenie miał w najnowszej historii Polski rok 1989 przypominać nie trzeba, warto spojrzeć natomiast na pewne, zwiazane $z$ nim, aspekty zmiany polityki narodowościowej. Po 1989 roku polska demokracja stanęła bowiem przed niełatwym wyzwaniem nowego ukształtowania tej polityki. Zadanie było tym istotniejsze, ale i trudniejsze, że w systemie komunistycznym, w Polskiej Rzeczypospolitej Ludowej, zagadnienia narodowościowe, jako kryjace w sobie duży potencjał konfliktów, znajdowały się pod restrykcyjna kontrola władz. Oznaczało to ścisła reglamentację pozwoleń na tworzenie organizacji mniejszości narodowych, zgodnie z zasada jedna mniejszość - jedno stowarzyszenie, oraz na wydawanie prasy. Narzędziami 
kontroli mniejszości narodowych była ponadto Polska Zjednoczona Partia Robotnicza (jej członkowie zajmujący kluczowe stanowiska w organizacjach mniejszości), cenzura oraz inwigilacja przez Służbę Bezpieczeństwa. Utrudniony był także kontakt $z$ krajami pochodzenia mniejszości, nawet gdy znajdowały się po tej samej stronie żelaznej kurtyny. Zagadnienia te sa dobrze znane i nie ma potrzeby szerzej ich tutaj omawiać. Można jedynie przypomnieć liczne opracowania dotyczące pierwszych lat powojennych oraz Eugeniusza Mironowicza, Politykę narodowościowa PRL (Białystok 2000) i Leszka Olejnika, Politykę narodowościowa Polski w latach 1944-1960 (Lódź 2003).

Zasady obowiazujące w systemie komunistycznym nie mogły, rzecz jasna, zostać zaakceptowane w systemie demokratycznym po przełomie 1989 roku. W demokratycznej opozycji istniało ponadto zrozumienie dla konieczności ukształtowania nowych relacji $z$ mniejszościami narodowymi. Jednak kształtowanie polityki narodowościowej, zgodnej $z$ europejskimi standardami, było procesem długofalowym, trwającym przez wiele lat. Ogromnie ważne było budowanie i poszerzanie społecznej akceptacji dla wprowadzanych rozwiązań, czyli dla traktowania członków mniejszości narodowych i etnicznych jako równoprawnych obywateli. Proces ten obejmował także bardzo ważny obszar regulacji prawnych zarówno w prawodawstwie wewnętrznym, jak i implementacji międzynarodowych rozwiązań prawnych. Jego częścią było ponadto tworzenie instytucji służacych realizacji tej polityki oraz modyfikowania instytucji już istniejących (np. szkolnictwa).

Przyjrzymy się tym punktom dokładniej, aczkolwiek w dalszych rozważaniach nie chodzi o szczegółową analizę kształtowania polskiej polityki narodowościowej po 1989 roku - wprowadzanych zmian, przyjmowanych aktów prawnych i procesów podejmowania decyzji, a o wskazanie zasadniczych ich uwarunkowań, czyli czynników przyspieszających albo blokujących dokonywane zmiany.

Na przykładzie Polski dobrze widoczna jest długofalowość tego procesu, a zarazem jego uzależnienie od polityki wewnętrznej. Oznacza to, że mamy do czynienia $z$ procesem przebiegajacym nierównomiernie. Tworzenie nowej polityki narodowościowej przebiegało najdynamiczniej w pierwszej fazie polskich przemian, płynąc na fali poparcia dla procesu demokratyzacji i liberalizacji. W ówczesnej atmosferze daleko idacej marginalizacji uległy w debacie publicznej, w mediach, postawy sprzeciwiające się zmianom, niechętne mniejszościom narodowym. $Z$ dzisiejszej perspektywy można nawet stwierdzić, że ich ówczesna marginalizacja i słaba słyszalność spowodowały niedocenienie wpły- 
wu, szerszego niż przypuszczano, jaki miały w społeczeństwie w kolejnych latach.

Niekorzystne zmiany następowały już w połowie lat 90 . XX wieku. Wcześnie okazało się, że stworzony system instytucjonalny nie był optymalny, zwłaszcza dotyczyło to ulokowania komórki (zmieniajacej swoja nazwę) zajmującej się w administracji państwowej mniejszościami w strukturze Ministerstwa Kultury i Sztuki. Było to ministerstwo słabe, mające niewielkie możliwości oddziaływania na politykę prowadzona przez inne resorty. System funkcjonował dość dobrze na początku lat 90. XX wieku, gdy komórka ta przekraczała zakres swych kompetencji, działając w korzystnym politycznym otoczeniu. Sytuacja zaczęła się jednak zmieniać wraz wyborami wygranymi przez Sojusz Lewicy Demokratycznej, po utworzeniu jesienia 1993 roku drugiego rządu Waldemara Pawlaka. Działania wspierające aktywność mniejszości były ograniczane. Kolejne opory na scenie polityczne pojawiały się w czasach rządów koalicji o bardziej prawicowym charakterze, w tym skupionych wokół Prawa i Sprawiedliwości. Mocniejsze otwarcie na prawe skrzydło sceny politycznej wywoływało w interesujacym nas obszarze napięcia, czego przykładem moga być te widoczne w województwie opolskim i katowickim wokół mniejszości niemieckiej ${ }^{1}$.

Nie oznaczało to powrotu do polityki narodowościowej sprzed 1989 roku i prowadzenia polityki sprzecznej z demokratycznymi zasadami, ale ograniczanie zasady pozytywnej dyskryminacji i wspierania aktywności mniejszości narodowych i etnicznych. W 1989 roku przyjęto wspomnianą zasadę jako służąca integracji mniejszości, przy zachowaniu ich tożsamości narodowej. Zgodnie $z$ nią, działalność mniejszości, mniej licznych i często rozproszonych, jest trudniejsza i wymaga większych środków finansowych, stąd powinna być szczególnie wspierana. Druga, kluczową zasadą było prawo do zachowania własnej tożsamości narodowej i etnicznej, czyli rezygnacja $z$ wszelkich form przymusowej asymilacji.

Dodajmy, że w opisywanym procesie ogromnie istotny był fakt działalności polityków wagi ciężkiej, którzy angażują się w problematykę mniejszości narodowych, popierają określone rozwiązania prawne i instytucjonalne, mobilizuja dla ich wprowadzenia poparcie na scenie politycznej. W Polsce taką rolę pełnił Jacek Kuroń, który

\footnotetext{
Dotyczyły one m.in. zwolnienia mniejszości z 5-procentowego progu wyborczego, które praktycznie miało znaczenie jedynie dla mniejszości niemieckiej. Por. Kaczyński: mniejszość niemiecka ma za duże przywileje, https://www.polskieradio24.pl/5/3/Artykul/741020,Kaczynski-mniejszosc-niemiecka-ma-za-duze-przywileje [dostęp: 18 października 2020].
} 
był jednym $z$ najważniejszych działaczy niepodległościowych przed 1989 rokiem, a następnie polityków III Rzeczypospolitej. To z jego inicjatywy powołana została w Sejmie Komisja Mniejszości Narodowych i Etnicznych, czyli stała komisja sejmowa, mająca na płaszczyźnie parlamentarnej kierować procesem tworzenia demokratycznej polityki mniejszościowej. Komisja ta, zwłaszcza w pierwszej fazie zmian, odegrała ogromna rolę $\mathrm{w}$ procesie kształtowania polityki narodowościowej. Można jednak powiedzieć szerzej, że Kuroń był animatorem, kreujaccym i wspierającym swoim autorytetem różne inicjatywy w interesującym nas obszarze. Swoim poparciem równoważył w pierwszych latach III RP opisane powyżej deficyty instytucjonalne, zapewniając przez swoje kontakty i wpływ polityczne poparcie dla zwolenników polityki pozytywnej dyskryminacji.

Sformułować można tezę, że równie ważne jak tworzenie instytucji i ważniejsze niż wprowadzanie konkretnych regulacji prawnych było budowanie atmosfery społecznej akceptacji dla mniejszości. Wprawdzie niezmiernie ważny jest też stosunek mniejszości do większości oraz do państwa, w którym zamieszkuje, ale - prawda to banalna - mniejszość znajduje się w relacji z większościa na słabszej pozycji, stąd ważniejsze było nastawienie polskiego otoczenia do współobywateli innej narodowości. Także w tym przypadku mamy do czynienia $z$ długotrwałym procesem, który nie zakończył się do dnia dzisiejszego i który nie zawsze oznacza liniową zmianę na lepsze. Jego częścia jest między innymi zaistnienie mniejszości w przestrzeni publicznej i związane $z$ tym napięcia albo akceptacja przez większość. W Polsce największe trudności w przezwyciężeniu niechęci lub wrogości dotyczyły dwu mniejszości, niemieckiej i ukraińskiej. W każdym przypadku uwarunkowania były odmienne, ale w obydwu osadzone były w historii.

Nastawienie polskiej większości do ukraińskiej mniejszości obciążała pamięć o II wojnie światowej i ludobójstwie dokonanym przez OUN-UPA na ludności polskiej na Wołyniu. Z kolei wśród mniejszości ukraińskiej dominowała pamięć o powojennych, w dużym stopniu przymusowych, przesiedleniach, głównie o tzw. Akcji „Wisła”. Na mniejszości niemieckiej ciążyła natomiast pamięć o okupacji niemieckiej w czasie II wojny światowej i popełnionych wówczas zbrodniach, w których współuczestniczyła duża część ówczesnych obywateli polskich narodowości niemieckiej. Ponadto mniejszość ta uwikłana była w całym okresie Polski komunistycznej w polsko-zachodnioniemiecki spór o ostateczny charakter polskiej granicy zachodniej. W Republice 
Federalnej Niemiec środowiska kwestionujace ostateczność polskiej granicy zachodniej powoływały się na fakt istnienia w Polsce mniejszości niemieckiej. Władze RFN, zainteresowane $z$ różnych względów podtrzymaniem dyskusji o granicy, liczebność tej mniejszości propagandowo wyolbrzymiały Natomiast władze polskie negowały jej istnienie (poza niewielka grupa na Dolnym Ślasku i Pomorzu), a twierdzenie o licznej mniejszości niemieckiej na ziemiach należących do 1945 roku do Niemiec traktowały jako śmiertelne niebezpieczeństwo dla Polski, zagrożenie jej integralności terytorialnej.

Pod wpływem opisanych historycznych obciążń aspiracje członków mniejszości ukraińskiej i niemieckiej do formalnego ich uznania po 1989 roku traktowane były przez większość społeczeństwa polskiego $z$ nieufnością. Dominowało przekonanie, że sa oni nielojalni i potencjalnie, na przykład w razie konfliktu w przyszłości, zagrażać będą bezpieczeństwu Polski. Także w tym przypadku warto zastanowić się, czy istniały czynniki, które odegrały specjalną rolę $\mathrm{w}$ zmianie tego niechętnego nastawienia. Za szczególnie istotne uznać należy dwa: jednostki o szczególnym wpływie oraz media. Zacznijmy od jednostek, które nie tyle oddziałuja na masy, co pełnia rolę zaczynu intelektualnego. Taką rolę odegrał w Polsce Bohdan Skaradziński, autor wydanej po raz pierwszy w 1983 roku pod pseudonimem Kazimierz Podlaski, i wielokrotnie wznawianej książki Białorusini, Litwini, Ukraincy. Dotyczyła ona stosunków Polaków z trzema wymienionymi narodami: Białorusinami, Litwinami, Ukraińcami, ale zwłaszcza $z$ obywatelami polskimi tej narodowości. W inny sposób oddziaływały media, co w pierwszej dekadzie przemian oznaczało przede wszystkim prasę, zarówno tę wydawana centralnie, jak i lokalną. Prasa centralna - szczególnie „Rzeczpospolita”, „Gazeta Wyborcza”, „Tygodnik Powszechny” - docierała do najszerszego grona odbiorców. Lata 90. XX wieku były jednak także okresem wyjątkowego rozkwitu prasy lokalnej, wydawanej często przez niewielkie, miejscowe środowiska. Chociaż docierała ona do znacznie węższego grona czytelników, to odegrała ogromna rolę, ponieważ duże zainteresowanie budziła historia najbliższych okolic, a w jej opisie pojawiały się osoby innej narodowości, nie jako obcy narodowo, jako mniejszości, lecz jako część lokalnej historii. Ogromna większość tych pism nie przetrwała kolejnych lat.

Postawy niechętne uznaniu mniejszości narodowych i przeciwne traktowaniu ich członków jako równoprawnych obywateli nie zniknęły w XXI wieku, ale reprezentowane były z czasem przez coraz mniejszą część polskiej większości. Ponieważ jednak istnieją one nadal 
w pewnym zakresie, potrzebna jest także w dniu dzisiejszym działalność edukacyjna, propagowanie postaw tolerancji i otwartości. Równie ważny jak demokratyczne wartości jest fakt, że polska racja stanu wymaga przezwyciężenia zamknięcia polskości w wąskich ramach etnicznych.

Dochodzimy do zagadnienia regulacji prawnych jako gwarancji praw mniejszości. Tutaj podkreślić trzeba, że dla zapewnienia zgodnych $z$ zachodnimi standardami praw mniejszości istotniejsze jest prawodawstwo wewnętrzne niż implementacja międzynarodowych aktów prawnych. Nie oznacza to, że te drugie nie sa istotne, ale nie one stanowią fundament, na którym opierają się prawa mniejszości. Służą przede wszystkim umocnieniu pozycji kraju w systemie demokratycznych państw, pokazaniu międzynarodowej opinii publicznej, że przestrzegane sa normy i wartości obowiąujące w świecie zachodnim. Sa niewątpliwie także stabilizatorem tych praw, gdyż ich naruszenie jest sprzeczne $z$ przyjętymi zobowiązaniami międzynarodowymi.

Na przykładzie Polski widzimy, że podstawowy zakres praw mniejszości narodowych i etnicznych (później uzupełniony o języki regionalne) określony został w trakcie dyskusji o tym, jaki powinien być kształt demokratycznego państwa polskiego i integracja w nim mniejszości. Stało się tak, mimo że władze centralne nigdy nie wypracowały całościowej koncepcji polityki mniejszościowej. Taki charakter miała jedynie uchwała rządu z 1996 roku, w której określone zostały podstawowe zasady polityki mniejszościowej. Dodajmy, że w dyskusjach istotne było odwołanie do integralności i bezpieczeństwa państwa polskiego.

Wprowadzane regulacje prawne podzielić można na te obejmujace całe społeczeństwo oraz te dotyczace praw mniejszości. Te pierwsze wiązały się $z$ ogólnym procesem demokratyzacji, ale należy docenić ich znaczenie dla mniejszości. Dla tych zamieszkujacych zwarte obszary szczególne ważna była ustawa o samorządach, umożliwiająca im udział w lokalnych władzach, dająca realny wpływ na lokalna politykę, w tym na budżet. Mniejszości uzyskały prawo zakładania bez ograniczeń, jak wszyscy obywatele, stowarzyszeń czy też wydawania prasy. Do historii przeszedł nadzór nad tymi działaniami przez Ministerstwo Spraw Wewnętrznych, a gdy problematyka ta wróciła po latach do tego resortu, zajmowanie się nią nie miało już nic wspólnego z policyjnym nadzorem czasu PRL. Członkowie mniejszości, tak jak wszyscy obywatele, zyskali prawo swobodnego przekraczania granicy i kontaktowania się $z$ krajem macierzystym. 
Ponadto przyjmowano regulacje prawne dotyczace jedynie mniejszości. Najwyższą rangę maja zapisy w Konstytucji. W art. 35 stwierdza się, że „1. Rzeczpospolita Polska zapewnia obywatelom polskim należącym do mniejszości narodowych i etnicznych wolność zachowania i rozwoju własnego języka, zachowania obyczajów i tradycji oraz rozwoju własnej kultury” oraz „2. Mniejszości narodowe i etniczne maja prawo do tworzenia własnych instytucji edukacyjnych, kulturalnych i instytucji służących ochronie tożsamości religijnej oraz do uczestnictwa w rozstrzyganiu spraw dotyczacych ich tożsamości kulturowej"2.

Obok niedyskryminacji przyjęto zasadę pozytywnej dyskryminacji, czyli przyznania członkom mniejszości pewnych specjalnych praw, jednakże służących nie ich uprzywilejowaniu, a majacych wyrównać ich szanse w obszarach, w których ich aktywność, jako rozproszonej społeczności, jest trudniejsza. Tu wymienić trzeba zwolnienie z konieczności przekroczenia progu wyborczego podczas wyborów parlamentarnych oraz stworzenie systemu dofinansowania działalności kulturalnej mniejszości (organizacje, prasa, imprezy kulturalne) funkcjonujący do dzisiaj, chociaż w mniej preferencyjny sposób niż w pierwszych latach po przełomie 1989 roku. Stworzono także w ramach systemu szkolnego system edukacji dla mniejszości. Niewattpliwie zakres pozytywnej dyskryminacji pozostaje do dnia dzisiejszego najbardziej kontrowersyjnym zagadnieniem, to co zwolennicy jej wzmocnienia uważają za wyrównanie szans, przez ich oponentów uważane jest za nieuprawnione uprzywilejowanie.

Równolegle następował od końca lat 90. proces implementacji prawa międzynarodowego. Do najważniejszych zaliczam po pierwsze Konwencję ramowa o ochronie mniejszości narodowych Rady Euro$\mathrm{py}^{3}$. Konwencja wymienia prawa i wolności przysługujace osobom należącym do mniejszości narodowych: m.in. prawo do swobodnego posługiwania się językiem ojczystym, zakaz dyskryminacji $z$ powodu przynależności do mniejszości narodowej czy etnicznej, prawo do nauki języka ojczystego oraz życia kulturalnego, wolność zrzeszania się i wyznania. Jednakże ze względu na rozbieżności stanowisk rząów państw nie nadano dokumentowi w pełni obligującej formy protokołu dodatkowego do Europejskiej Konwencji Praw Człowieka. Konwencja

\footnotetext{
2 Konstytucja Rzeczypospolitej Polskiej, https://www.sejm.gov.pl/prawo/konst/polski/kon1.htm [dostęp: 14 października 2020].

3 Konwencja ramowa o ochronie mniejszości narodowych z 1 lutego 1995 r., „Dziennik Ustaw" 2002, nr 22, poz. 209.
} 
raczej zawiera stwierdzenia programowe, pozostawiając rządom swobodę określenia konkretnych działań. Drugim ważnym aktem jest Europejska karta języków regionalnych lub mniejszościowych poświęcona ochronie i promocji języków mniejszościowych i regionalnych ${ }^{4}$. Określa środki, jakie państwo powinno wprowadzić, by chronić te języki (edukacja, wymiar sprawiedliwości, administracja, media itd.). Konwencja i Karta są ważne jako definiujące i stabilizujące kierunki polityki, ale zawarte $\mathrm{w}$ nich sformułowania maja ogólnikowy charakter, słabe sa mechanizmy weryfikacji realizacji zobowiązań i narzędzia sankcji, w razie ich niewypełniania.

W 2005 roku przyjęta została ustawa o mniejszościach narodowych i etnicznych oraz o języku regionalnym ${ }^{5}$. Jest ona tym istotniejsza, że jej projekt budził duże kontrowersje wewnątrzpolityczne zarówno co do pewnych rozwiązań, jak i - co ważniejsze - odnośnie do samej idei stworzenia takiego odrębnego aktu prawnego. Ostatecznie, przewagę zyskała opinia, że służyć on będzie ustabilizowaniu mniejszości, zwiększy ich pewność posiadania i egzekwowania praw. Poza zebraniem regulacji prawnych dotyczacych mniejszości, zawartych w różnego rodzaju aktach prawnych, oraz zdefiniowaniem pewnych terminów, czyli działaniem o charakterze porząkującym, w ustawie wprowadzono możliwość stosowania dwujęzycznych nazw topograficznych i języka mniejszości jako języka pomocniczego. W chwili obecnej ustawa nie budzi większych emocji, została zasadniczo zaakceptowana. Jest ona ciekawa także dlatego, że proces jej uchwalania pokazuje, jak ważne jest, aby wprowadzane akty prawne cieszyły się społeczna akceptacją, a nie były odgórnie narzucane. Nad wspomniana ustawą dyskutowano około dziesięciu lat i część jej zapisów budziła początkowo sprzeciw większości polityków i społeczeństwa. Kilkuletnia dyskusja całkowicie oporów tych nie zlikwidowała, do dzisiaj zdarzaja się przypadki konfliktów i zamazywania dwujęzycznych tablic, ale większość społeczeństwa zaaprobowała proponowane rozwiązania. W tej perspektywie wydaje się, że kilkuletnia zwłoka w przyjęciu ustawy miała pozytywne znaczenie, była swego rodzaju procesem edukacji w zakresie praw mniejszości.

$\mathrm{Na}$ koniec przypomnijmy, że polskie doświadczenie potwierdza, że mimo przyjęcia wielu aktów prawnych proces określania miejsca

\footnotetext{
${ }^{4}$ Europejska karta języków regionalnych lub mniejszościowych z 5 listopada 1992 r., „Dziennik Ustaw” 2009, nr 137, poz. 1121.

5 Ustawa $z$ dnia 6 stycznia 2005 r. o mniejszościach narodowych $i$ etnicznych oraz o języku regionalnym, „Dziennik Ustaw” 2005, nr 17, poz. 141.
} 
mniejszości w państwie i społeczeństwie nigdy się nie kończy. Nie zakończyło jej przyjęcie wspomnianej ustawy z 2005 roku. Pierwsza płaszczyznę stanowi sposób realizacji posiadanych praw. Jak szeroka powinna być obecność mniejszości w mediach, w tym tych droższych, czyli telewizji? Czy wystarczające sa dotacje przyznawane na działalność kulturalna, w tym na prasę mniejszości? Czy optymalny jest system edukacji dla mniejszości (także obecnie trwa spór wokół formy nauczania języka mniejszości i języków obcych)? Jak pogodzić przy poszerzaniu granic interes miasta wymagającego rozwoju (np. Opola) $z$ interesem mniejszości, obawiającej się utraty dotychczasowych praw? Podobne pytania można kontynuować, będąc zarazem pewnym, że będa one powracać w kolejnych latach.

W demokratycznym systemie prawa mniejszości i ich realizacja sa ciagłym wypracowywaniem wewnattrzpolitycznego kompromisu. Wypracowywaniem w zmieniajacym się układzie społecznym i politycznym. Mniejszości zgodnie $z$ prawem polskim podzielono początkowo na narodowe i etniczne. Różni je to, że mniejszości narodowe utożsamiaja się $z$ narodem zorganizowanym we własnym państwie, a etniczne (jak Łemkowie czy Karaimi) nie. Wkrótce okazało się, że niezbędne jest wprowadzenie kategorii języka regionalnego. Jest to język, nie dialekt języka oficjalnego, „używany na terytorium danego państwa przez jego obywateli, którzy stanowia grupę liczebnie mniejszą od reszty ludności tego państwa", ale nie sa mniejszością narodową albo etniczna. Za grupę taką uznano Kaszubów, zamieszkałych na północy Polski. Wkrótce jednak postulaty przyznania podobnych praw zaczęła formułować część Ślązaków, a kontrowersje czy etnolekt śląski jest językiem, czy dialektem języka polskiego, oraz czy istnieje narodowość śląska, trwaja nadal.

Mniejszości podlegaja dynamicznym zmianom wewnętrznym. W demokratycznym systemie, w którym, nawet mimo wahnięć w polityce władz wobec mniejszości narodowych i etnicznych, niewielkie jest zagrożenie dla ich tożsamości narodowej, słabnie polityczna mobilizacja. Nawet zamieszkałej zwarcie mniejszości niemieckiej coraz trudniej jest wybrać liczniejszą reprezentację do parlamentu. Warto także pamiętać o zmianach generacyjnych ${ }^{6}$. Przemiany tożsamości narodowej dokonuja się szczególnie silnie w młodym pokoleniu, nie pamięta-

\footnotetext{
6 W „Gazecie Opolskiej” z 23 października 2007 r. Marek Świerszcz napisał (Koniec epoki Henryka Krolla): „Koniec poselskiej kariery Krolla to także koniec pewnej epoki w dziejach opolskiej mniejszości niemieckiej”. To samo sformułowanie można powtórzyć w odniesieniu do wielu liderów innych mniejszości.
} 
jącym już czasów komunistycznej Polski. Ciekawym przykładem jest wzmacnianie się tożsamości śląskiej, co odbywa się, jak można przyjąć na podstawie spisów ludności, kosztem mniejszości niemieckiej. Okazało się, że opisana przez Lecha Nijakowskiego w książce Domeny symboliczne: konflikty narodowe $i$ etniczne $w$ wymiarze symbolicznym rywalizacja rozgrywa się - co pokazało wykorzystanie symboliki polskiego, komunistycznego obozu dla Niemców, który istniał w Świętochłowicach - także między mniejszościami zarówno tymi uznawanymi, jak i nieuznawanymi.

Ponadto w wyniku migracji znalazła się po 1989 roku w Polsce liczna grupa Ukraińców i Białorusinów, także widoczna Wietnamczyków oraz osób należących do innych narodowości i religii. Napływ migrantów do Polski nabrał w dwóch dekadach XXI wieku na sile. Nie sposób obecnie przewidzieć, jak przebiegał będzie proces ich integracji, czy ukształtują się jako mniejszości, czy też - i w jakiej części - ulegna asymilacji.

Powyższe przykłady pokazuja, jak dynamicznym zmianom podlegaja w każdym społeczeństwie różne grupy i ich tożsamość oraz to, że wypracowywanie między nimi kompromisu trwać będzie nadal. Ważne jedynie, by zachowane zostały przy tym demokratyczne procedury, a same mniejszości nie były wygrywane w polityce wewnętrznej i w relacjach $z$ innymi krajami. 